\title{
Formulating a Long Term Strategy for Sustainable Palm Oil Biodiesel Development in Indonesia
}

\author{
Beny A. Purwanto ${ }^{1,2,3}$, Erliza Hambali ${ }^{2,4}$, Yandra Arkeman ${ }^{2,4}$ \& Hendri Wijaya ${ }^{4}$ \\ ${ }^{1}$ Directorate of Machinery and Agricu lture Equip ment Industry, Ministry of Industry, Indonesia \\ ${ }^{2}$ Agro indus trial Technology Study Program, Graduate School, Bogor Agricultural University (IPB), Indonesia \\ ${ }^{3}$ Entrepreneurship, Commercialization \& Innovation Centre, The University of Adelaide, Australia \\ ${ }^{4}$ Surfactant and Bioenergy Research Center, Bogor Agricultural University (IPB), Indonesia \\ Correspondence: Erliza Hambali, Surfactant and Bioenergy Research Center, Bogor Agricultural University \\ (IPB), Kampus IPB Baranangsiang Jl. Padjajaran No1 Bogor 16144 Jawa Barat, Indonesia Tel: 622-5-1 \\ 833-0970. E-mail:erliza.h@g mail.com
}

\author{
Received: March 30, 2016 Accepted: June 9, 2016 On line Published: July 30, 2016 \\ doi:10.5539/jsd.v9n4p124 URL: http://d x.doi.org/10.5539/jsd.v9n4p 124
}

\begin{abstract}
Indonesia, the largest producer of palm oil, has been developed palm oil biodiesel as renewable energy in the last decade. Indonesia biodiesel development policies aim to increase domestic value added of palm oil product and reduce the reliance on fossil fuel. Indonesia has embarked on a comprehensive palm oil biodiesel program since 2006 and targeted the $20 \%$ biodiesel blend (B20) in 2016. This article explores the strategy formulation by accommodate the stakeholder perspective in the problems and the solutions. This research analyzes the information from in depth interview with biodiesel stakeholders (government, industry and researcher) in Indonesia by combine Strengths, Weaknesses, Opportunities, and Threats (SWOT) analysis with a Multi Actor Analysis approach. The results show the problems of biodiesel development are mainly on the high production cost due to high price of raw material, production technology and distribution infrastructure. The government policy, technology development and raw material supply are the driving forces of the biodiesel development in Indonesia. In the long term strategy, government of Indonesia should secure the biodiesel raw material, develop an environmental friendly technology in biodiesel processing, and accommodate any improvement idea from other stakeholders.
\end{abstract}

Keywor ds: biodiesel, bioenergy, palm oil, policy, stakeholders, sustainable

\section{Introduction}

Since 2008, Indonesia is net importer of petroleum. The national production capacity of petroleum cannot fulfil the national demand. In the 2013, the total consumption of petroleum is 72 million kilolitre (diesel fuel: 34 million kilolitre). In the supply, the import nu mber of petroleu m reach 32 million kilolitre (diesel fuel: 11 million kilolitre), then $44 \%$ of the petroleu m supply in Indonesia is imported.

The government sees the opportunity to reduce petroleum import by utilize biofuel. The govern ment promotes bioethanol to substitute gasoline and biodiesel to substitute diesel fuel. In the progress, the development of bioethanol is stagnant. It was caused by Indonesia is lack of glucose and starch as raw material of bioethanol. Only biodiesel is success in the development because Indonesia has adequate Crude Palm Oil (CPO) as raw material.

In the first step of the biofuel program, the Indonesia Government through National Biofuel Team formu lated a regulation on the biofuel mixing up to 5\% (B5). The regulation is Presidential Regulation No.5/2006 on National Energy Policy, calling for 5\% biofuels in the energy mix by 2025 . And then, government established by the National Team for Biofuels Development to coordinate industry expansion in July 2006. On the biofuel, National Team for Biofuels proposed development of Bioethanol from sugar cane or cassava and Biodiesel from palm oil or Jatropha Curcas. Until now, only palm oil biodiesel has been developed on industrial scale.

For the raw material supply, palm oil plantation in Indonesia is 7.9 million hectare, produce 26.5 million ton of CPO (exported: 18.1 million ton, domestic use: 8.4 million ton) - the biggest in the world. As listed in Ministry 
of Energy and Natural Resources, there are 26 biodiesel companies with the total national capacity about 5.6 Million kilolitre/year. Those regulations successfully got the attention from the investor.

In the demand side, the government regulated mandatory blending of biodiesel, believing it will generate domestic demand for biodiesel that will encourage the growth of the biod iesel industry. In 2006, the govern ment target of biodiesel mandatory blending is 5\% (B5). So the total demand of biodiesel will reach 1.3 Million Litre, Considering the target $5 \%$ biodiesel blending and the national demand of diesel fuel (26 Million Litre).

In 2013, government increase the biodiesel mandatory blending to $10 \%$ because the government wants to save the petroleum import budget. Central Statistics Agency (Badan Pusat Statistic - BPS) recorded the Indonesian trade balance during January 2013 a deficit of 430.6 million U.S. dollars, which is derived from the value of exports 14.48 billion U.S. dollars and imports amounted to 14.92 billion U.S. dollars, one reason is the increasing imported fuel oil by the government to meet domestic demand. Based on BPS data, one of the triggers of the trade deficit in the early years due to high oil and gas imports to reach 3.55 billion U.S. dollars, while exports of oil and gas is only 2.49 billion U.S. dollars. To solve the trade deficit, the government is try ing to reduce the value of imports by substitution with goods produced in the country. Thus the government is try ing to reduce imports of diesel fuel by using biodiesel blends, which Indonesia has a huge palm oil production as a raw material for biodiesel. One of government action was increase the biodiesel mandatory blending of 5\% to $10 \%$.

\section{Indonesia Biodiesel Policy}

The aims of the biofuel development were to improve energy security, boost economic growth, create employ ment and reduce poverty in rural areas (Wirawan \& Tambunan, 2006). The objectives have similarity with other developing countries in South East Asia like Malaysia, Thailand and Philippines. The main objective of the biofuel development policy was to reduce the dependence on oil import as a socio-economic concern, but also to increase employment and income generating opportunities in the rural areas. Climate change is currently not the primary motive of these countries to pursue biofuel development policies (Kumar, Shrestha, \& Salam, 2013).

Biodiesel is made from biological resources such as vegetable oils or animal fats. The main compound of biodiesel is a methyl ester compound. Biodiesel can be made from the trans esterification of fatty acids. Fatty acids, from vegetable oils, are mixed with fatty esters and alcohol to produce by products such as glycerin. In the market, glycerin has a high economic value.

Biodiesel has been widely used as a substitute for diesel fuel. Biodiesel feedstock development depends on the natural resources of a nation, for example canola oil in Germany and Austria, soybean oil in USA, palm oil in Malaysia and Indonesia, coconut oil in the Philippines (Abdullah et al., 2009)

The national team of biofuels provided a biodiesel development roadmap in 2006. They targeted to use $10 \%$ biodiesel from total consumption of Automotive Diesel Oil (ADO) in 2006 - 2010 and then increased until $20 \%$ in 2016. The target of biodiesel usage from total usage is ambitious (Carokoet el al., 2009). Increasing mandatory blending is one of the policies to increase biodiesel usage (Handoko, 2012), but the problem of palm oil biodiesel continue from the plantation until distribution. The govern ment should provide a set of effective regulation in the biodiesel supply chain (Daryanto, 2010).

In 2014, the government targeted to increase biodiesel mixing to $10 \%$ (B10) that was stated in Minister of Energy and Mineral Resources Regulation No: 20/2014. This regulation targeted to utilize the biodiesel in Transportation, Industry and Power Plant sector.

\section{Policy Analysis in Multi Actors}

In Indonesia, biodiesel development was conducted by government with the support from industry, academics, research center and palm oil grower. This means the biodiesel development policy is mu lti actor policy. In this condition, every problem in the formulating and the implementation of the policy is become complicated. Different actor has their own view on the problems and also on the solutions.

The model of policy analysis in multi actor organizes the stakeholder in the network rather than classic hierarchy. This means the desired solutions is products of cooperation among the actors (Enserink et al., 2010).

The policy analysis in multi actors system starts with problem formulation. Every actor provides problem and solutions according their perspective. And then the analysis divided into three methods:

1) System Analysis

The system analysis provides conceptual framework of the system, the area of research, and also identified the means, external factors and criteria. The steps in system analysis are problem demarcation, specify object and 
criteria, identify the means and map the main causal, and the last is provide of the problem area using a system diagram.

\section{2) Actor Analys is}

Identifying the problems of biodiesel could start by analyzing the role of the stakeholders. The stakeholder definitions depend on the interest, role, power and impact. Knowing who the key actors are, their knowledge, interests, positions, alliances, and importance related to the policy allows policy makers and managers to interact more effectively with key stakeholders and increase support for a given policy or program (Schmeer, 1999). Furthermore, failure to attend to the information and concerns of stakeholders clearly is a flaw in thinking or action that too often and too predictably leads to poor performance, outright failure or even disaster (Bryson, 2004).

Understanding the stakeholder will provide a firm base to develop the strategy. In case of biodiesel development in Indonesia, how far the government understands the issues and shows concerns for the stakeholder interest is questionable. The blueprint of biodiesel develop ment was developed with limited involvement from stakeholders such as the uncertainty (Caroko et al., 2011).

Stakeholder input was sought only when the final draft was released. In this stage, the government of Indonesia was unable to involve the key stakeholders in the biodiesel development and this condition generated many problem and obstacles in the policy implementation.

\section{3) Scenario Analysis}

Scenario analysis provides the alternative of the future according to the present issue. The future is hard to predict but the scenario analysis of alternative can be used to predict the future. The main activity is determining the contextual factors in the present and then finds the driving forces. According to the driving forces impact and the scenario of the policy in the future can be predicted

Multi actor analysis utilizes the above analysis to provide recommendation to improve the policy and also provide alternative strategy in the implementation of the policy.

\section{Bioenergy Sustainable De velopment}

Sustainable development has caught the researcher spotlight lately. Many organizations like profit, non-profit, public, government and NGO have promoted the label sustainable development. Sustainable development, although a widely used phrase and idea, has many different meanings and therefore provokes many different responses. In broad terms, the concept of sustainable development is an attempt to combine growing concerns about a range of environmental is sues with socio-economic issues (Hopwood, Mellor, \& O'Brien, 2005).

The separation of environment, society and economy often leads to a narrow techno-scientific approach, while issues to do with society that are most likely to challenge the present socio-economic structure are often marg inalized, in particu lar the sustainability of communities and the maintenance of cultural diversity (Giddings, Hopwood, \& O'brien, 2002).

Sustainable development analysis of palm oil biodiesel is sequenced steps started with defining the system boundary biodiesel and then followed by identify ing the kinds of impacts (economic, environmental, and societal). This impact would accrue as a result of the biodiesel development, then identifying, selecting, and prioritizing the indicators to be used to evaluate the alternative routes for sustainability evaluation. Comparison of the indicators data will lead to a decision on which of the alternatives is more sustainable (Mata et al., 2011).

In term of sustainability of bioenergy, there are some approaches to guarantee the sustainability of biod iesel in Indonesia. In the supply side, the palm oil plantations and palm oil mills has to certify by ISPO (Indonesia Sustainable Palm Oil) as the implementation of RSPO (Roundtable Sustainable Palm Oil). In biofuels, The Global Bioenergy Partnership (GBEP) established the GBEP Task Force on Sustainability to promote sustainable production and use of bioenergy. GBEP members are 27 countries (include Indonesia) and 12 International Organizations and institutions and further GBEP partners reach 23 countries and 14 international organizations and institutions.

The 24 indicators of sustainable bioenergy development were grouped in three pillars, i.e.: enviro nmental, social and economic (GBEP, 2012). The indicators are starting points from which policy-makers and other stakeholders can identify and develop measurements and domestic data sources that are relevant to their nationally-defined needs and circumstances.

In the future, all the strategy of biodieseldevelop ment in the as pect of supply raw material and de mand of biodiesel usage have to acknowledge the sustainable development criteria. The sustainability is the most important in the 
policy decision. For example in the supply of raw material, the future raw material of biodiesel must be environmental friendly, accepted socially and feasible economically.

The connection between sustainable development and entrepreneurship depend on many factor, for example : business sector, industry structure and the dynamics of its interp lay, and a lso depend on trade off a mong co mpeting economic, social and environ mental aspects (Hall, Danneke, \& Lenox, 2010). Biodiesel sustainable development in Indonesia is to be made the responsibility of the entrepreneur. The condition of economic side of biodiesel business is not profitable. The biodiesel development is government initiative to increase the value added of palm oil product and reduce the dependency to petroleum import (Daryanto, 2010). In the result, the government is the main driver of sustainable development of biodiesel in Indonesia.

Biodiesel development program has been executed for 9 years. The government has made some change on the policy many times. Those changes were decided by the government to catch the opportunity to grow the economic by utilizing biodiesel industry, but the government did not give the attention to the problems and solutions of the stakeholder. This condition made the implementation of biodies el development policy did not effective. This research is approaching the stakeholder's perspective to formulate the problem, provide the scenario of future, and recommend the long term strategy to sustain the biodiesel development in Indonesia.

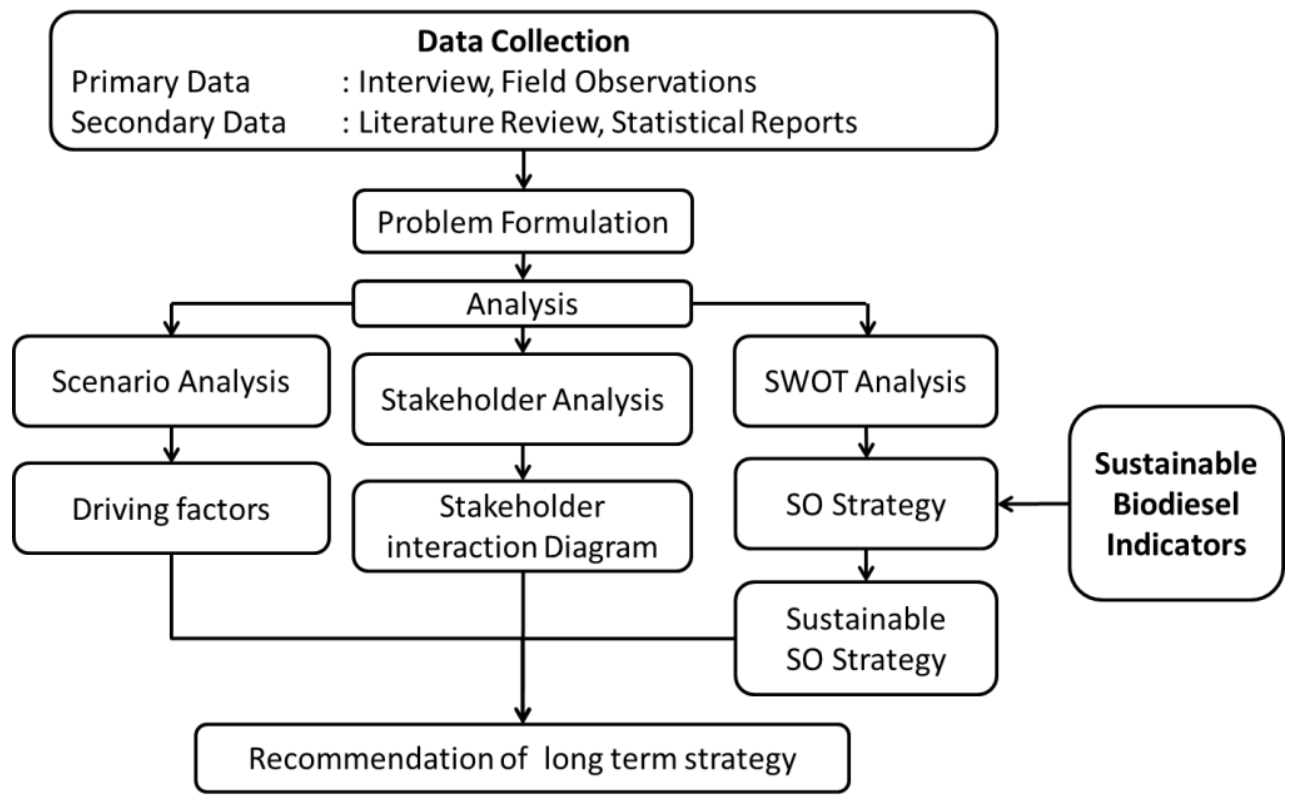

Figure 1. Research frameworks

\section{Research Method}

The research was conducted through a case study methodology with the qualitative approach. The research is conducted by using data from Indonesia palm oil biodiesel experts. The criteria of expert come from their activities in the biodiesel development in Indonesia. The supply chain of biodiesel product in Indonesia starts with palm oil plantation then continues through to distribution at the gas station. The research framework is illustrated in figure 1.

An interview script that had open-ended questions was used. The semi-structured interviews were conducted and recorded, mostly about 30-60 minutes for each respondent; a series of notes was made during the interviews. The respondents were the head of divisions and directors of each company. Data of field observation were also collected.

Thematic analysis was used to analyze the result of the interviews. Firstly, all intervie ws were audio recorded on tape, then listen repeatedly, transcript and coded as proposed by Creswell (Creswell, 2013). After the coding of the material, some nodes were created and categorized following the already established frame work from the literature reviews (Yin, 2013). Problem formulation is the early step in multi actor policy analysis, continued by scenario analysis and actor analysis by using stakeholder analysis. The stakeholder analysis is conducted to analyze the interest, power and relation among the stakeholders.

SWOT is an acronym for Strength, Weaknesses, Opportunities, and Threats. As the name implies, SWOT 
analysis is used to identify the strengths, weaknesses, opportunities and threats. It is used to decide on the actions to be taken after the ele ments of SWOT have been determined (Mason, 2011).

\section{Problem of Biodiesel Development}

The problems faced by the biodiesel industry are similar to the problems faced by the industry at large in Indonesia. The problems associated with the distribution of goods in Indonesian infrastructure. A Study cases in Dumai, as a city that has the largest biodiesel industry in Indonesia. Dumai sea port has a small capacity for handling CPO and biodiesel. This resulted in the duration of loading and unloading at the port that increased cost of the port.

Furthermore, in terms of raw material, biodiesel in Indonesia relies heavily on palm oil, as palm oil is the only raw material that is successfully developed in Indonesia. Initially, raw material for biodiesel that is developed there are several including Jatropha curcas, Reutealis trisperma (Blanco) Airy Shaw, used cooking oil, and palm oil, but only palm oil growing up at industrial scale. For biodiesel industry which has an oil palm plantation, availability of raw materials not crucial problem, but for industries that do not have oil palm plantation, availability of raw materials is the dominant is sue they face each year.

CPO supply in the future can also be a problem for the biodiesel industry as CPO also used by other industries such as food and cooking oil. And the food industry has a higher profit marg in than the biodiesel industry. Large scale Biodiesel companies also produce many palm oil product for food, cosmetic, pharmaceutical and biodiesel. If biodiesel product does not provide feasible profit, the management change their production focus on the others product.

The next problem of the biodiesel program is the lack of standard rules in the selling price of biodiesel in Indonesia. PERTAMINA as the sole purchaser of biodiesel submit a pricing mechanis m to the government, but until now the standard price that should be used is still unclear. In Indonesia, there are three standard selling price of biodiesel is

1) MOPS (Mean of Plats Singapore) standard, biodiesel price depend on petroleum price

2) Export Price Standards, biodiesel depend on the global biodiesel price.

3) Production Cost Standard, biodiesel price depend on the biodiesel production costs.

Third standards above have fluctuating prices, respectively, and the government should immediately set the standard prices prevailing at PERTAMINA. The quality of biodiesel produced by each uncontrolled biodiesel industry, in particular small and medium-scale industry that does not have complete testing facilities. Poor quality of biodiesel will lead to problems on machines that use biodiesel. The last problem is the environmental issues. As the only raw material, palm oil still has homework related to deforestation, land acquisition, and greenhouse gas emission.

Overall, the problems in biodiesel development in Indonesia are:

1) High cost production due to price of $\mathrm{CPO}$, production technology and infrastructure of distribut ion

2) Different pricing standards

3) Biodiesel Standardization: low quality control

4) Environment issue: deforestation, fire, GHG Emission and social problem

5) Biodiesel depends on palmoil supply

The biodiesel development faced obstacles in Technical, Financial, Regulation, Social and Market (Daryanto, 2010). Those obstacles are arising until now, even though government has revised the biodiesel policy. The government should accommodate the solutions offered by the other stakeholders.

\section{Driven Factors on Biodiesel Development}

The available data indicate that the realization of the absorption of biodiesel in 2010 and 2011 respectively by $20.73 \%$ new and $27 \%$ of the target set. Based on the information from Indonesia Biofuel Producers Association (APROBI), pricing policies are the main cause on business and not optimal absorption of biofuel in Indonesia.

The government has issued several regulations related to business and the use of biofuel. The increase in oil prices was high enough in 2005 to force the government to raise subsidized fuel prices. This is the driving factor for the development and utilization of biofuel for domestic interest.

During its development, the use of biofuels as mandated in the Minister of Energy and Natural Resource did not run consistently. Based on existing data, almost $100 \%$ biodiesel usage is made by the transport sector. However, 
the policy also mandates that the biodiesel has to be utilized by the industrial sector, commercial, and power plants. However, after eight (8) years after the implementation of these regulations, there is still no biodiesel use by non-transport sector like industry and power plant.

According to the contextual condition below, each of contextual factors will be analyze to determine the driving forces of each contextual factor. The detail contextual factors and driving forces provide in table 1 .

The driving factors of biodiesel development in Indonesia are government policies, technology development, raw material supply, infrastructure, international factors and economic feasibility. In recent condition, government policies and raw material supply is the main driving forces. In the future, technology development and economic feasibility can be the main driving forces.

Table1. Driving forces of biodiesel develop ment

\begin{tabular}{lll}
\hline No $\quad$ Driving forces & Contextual factors \\
\hline A & Government Policy & Biodiesel demand on fuel \\
& & Biodiesel demand on industry and power plant \\
& Price of biodiesel \\
& Government incentive \\
& Government subsidy \\
& Biodiesel \& CPO tax policy \\
& Biodiesel standardization \\
& & Technology development in biodiesel production \\
& Technology development in biodiesel usage \\
B & Technology Development & Technology development in CPO usage \\
& & Technology development in other renew able energy \\
& & Environment issue \\
& & Customer acceptance \\
& & Supply of CPO \\
& & Price of CPO \\
C & Raw Material Supply & Supply of other biodiesel raw material \\
& & Biodiesel distribution infrastructure \\
& & Biodiesel blending facility \\
& & Biodiesel production \\
D $\quad$ Infrastructure & Export biodiesel \\
& & Price of petroleum \\
& & Demand of CPO in food product \\
& & Profitability of biodiesel \\
& & Profitability of food product \\
\hline & &
\end{tabular}

\section{Long Term Strategy of Biodiesel De velopment}

From 2006 until 2015, biodiesel program has developed to supply the domestic market and global market. The focus of formulated strategy is on the domestic market. Govern ment has targeted to use $20 \%$ biodiesel blending in 2016. SW OT analysis will provide the current position of the biodiesel program implementation and then draw the strategy to sustain the development of biodiesel program.

\section{SWOT Strategy Analysis}

- Strength: adequate supply of raw material and support from the governments.

- Weakness: low support in technology, quality issue, and the resources depend on CPO. 
- Opportunity: economic growth, Industrial collaborative is sue, Increasing demand in industrial and power plan sector.

- Threat: food vs fuel issue of CPO product, environment issue, and public acceptance of high biodiesel blending (B20).

On the long term strategy, the government should focus on the strength of biodiesel program to get the opportunity. The strength of this program is stakeholders support and adequate source of biodiesel raw material. In Indonesia, Government is the main actor of the Biodiesel Development, so the long term strategy that should be taken by government in support the research in development of new raw material and the development of biodiesel technology, for both in the production technology and also usage technology in vehicle, industrial mach in ery and power plant.

The imp le mentation of the long term strategy depends on the interaction among stakeholders. According to Caroko et al. (2011), there are 9 key stakeholders in biodies el development according to the interest and motivation but in this research we focus on specific biodiesel stakeholder without the stakeholder of CPO.

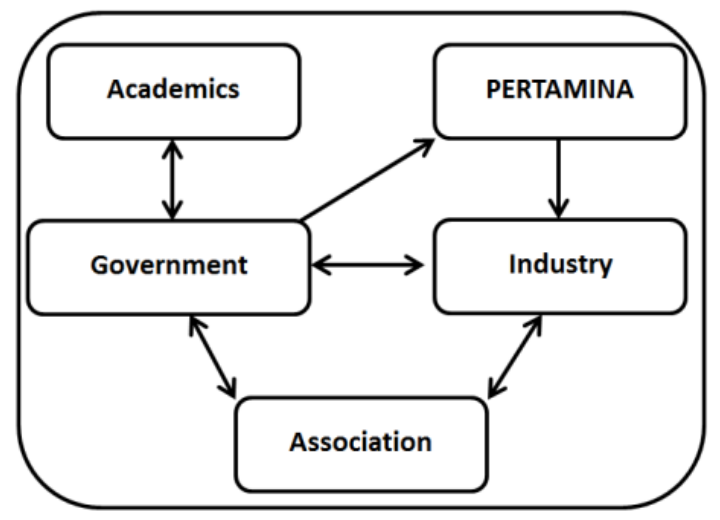

a. Recent Stakeholders Interactions

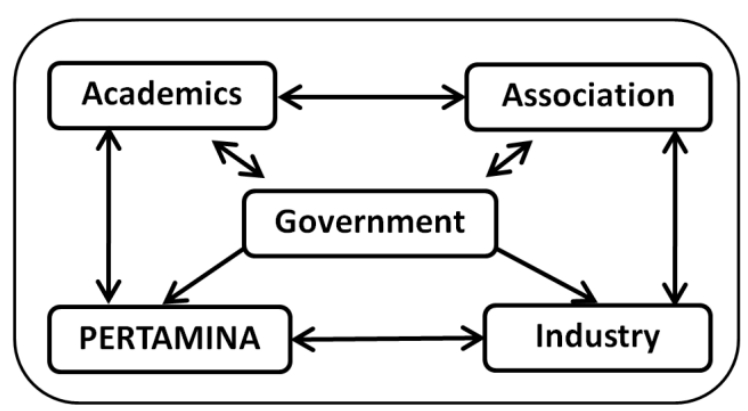

b. Improved Stakeholders Interactions

Figure 2.Interactions of biodies el stakeholders

From the figure 2, the current interaction of biodiesel stakeholders is only dominated by government. The bold arrow shows a high influence on the biodiesel program. The government has high in fluence to PERTAMINA in case of biodiesel blending. Same condition is happening from PERTAMINA to the industry. The influence of PERTAMINA to the biodiesel industry is very high because PERTAMINA is the only buyer of biodiesel in Indonesia. The government develops the biodiesel development policy with their own knowledge. The academics influence to the government is low, their opinions on the biodiesel development is neglected by the government.

\section{Conclusion and Recommendation}

Developing of sustainable raw material of biodiesel is the first key of sustainable biodiesel development in Indonesia. The criteria of raw material are environ mental friendly, accepted socially and feasible economically. According to GBEP report (2014), the current is sues of sustainable CPO and Biodiesel industry in Indonesia are Green House Gas (GHG) emission, water pollution and habitat loss and the impact in biological diversity. The GHG emission coming from forest fire, peat decomposition and fermentation of palm oil mill effluent (POME), 
The first key of long term strategy in biodiesel development is guarantee the sustainable raw material of biodiesel especially CPO. The government should secure the supply of CPO as raw material of biodiesel by providing sustainable palm oil plantation exclusive to biodiesel.

The second key of sustainable biodiesel development is technology development. The government should support the research on the development of biodiesel production technology. The latest technology in biodiesel development is to develop continous system of biodiesel processing without catalyst. The bioprocess technology will reduce the production cost and infestation cost. The technology in the biodiesel utilizations also should be developed. Until now, the maximum biodiesel blending on the standard engine is $20 \%$, higher biodiesel blending will make some problem to the engine and fuel pump. The others technology that has been developed is Catalytic Hydrocracking Technology. This technology claimed that able to use $100 \%$ of biodiesel. Some automotive manufacture company has started the development of this technology.

In formu lating long term biodiesel strategy, government should accommodate the idea from other stakeholders like Academics and Association. In the stakeholder relationship, the biodiesel experts including academics, researcher, and industrial consultant should has more knowledge power to influence the government in the formulating biodiesel policy. The academics and biodiesel industry should create a joint research in biodiesel technology, because both of them have different knowledge that will be very useful to share

This research was conducted in small number of stakeholders and the interview question cannot explore the stakeholder perspective in detail. The bigger sample will provide better identification of motivation, interest and connection to all the biodiesel stakeholders. The next research should identify the supply and demand of the biodiesel in detail. Further research should exp lore the cost and benefit analysis of biodiesel in the future.

\section{References}

Abdullah, A.Z., Salatinia, B., Mootabdi, H., \& Bhatia, S. (2009). Current status and policies on biodiesel industry in Malaysia as the world's leading producer of palm oil. Journal : Energy Policy, 37(12), 5440-5448. http://dx.doi.org/10.1016/j.enpol.2009.08.012

Bryson, J.M. (2004). What to do when stakeholders matter: stakeholder identification and analysis techniques. Public management review, 6(1), 21-53. Retrieved from http://www.tandfonline.com/doi/abs/10.1080 /14719030410001675722

Caroko, W., Ko marudin, H., Obid zinski, K., \& Gunarso, P. (2011). Policy and institutional frameworks for the development of palm oil-based biodiesel in Indonesia. CIFOR. Retrieved from $\mathrm{http} / / /$ www.cifor.org/library/3660/policy-and-institutional-fra meworks-for-the-development-of-palm-o il-ba sed-biodiesel-in-indonesia/

Creswell, J.W. (2013). Research design: Qualitative, quantitative, and mixed methods approaches. Sage publications.

Daryanto, A.(2010). Urgensi pengembangan sumber energi terbarukan. Retrieved from http://agrimedia.mb.ipb.ac.id

Enserink, B., Kwakkel, J., Bots, P., Hermans, L., \& Thissen, W. (2010). Policy analysis of multi-actor systems. The Hague: Lemma.

GBEP. (2010).The Global Bioenergy Partnership Sustainability Indicators for Bioenergy. FAO Rome, Italy. Retrieved from https://inis.iaea.org/search/search.aspx?orig_q=RN:43093773

Giddings, B., Hopwood, B., \& O'brien,G. (2002). Environ ment, econo my and society : fitting them together into sustainable development. Sustainable Development. http://dx.doi.org/10.1002/sd.199

Hall, J.K., Daneke, G.A., \& Lenox, M.J. (2010). Sustainable development and entrepreneurship: Past contributions and future directions. Journal of Business Venturing, 25(5), 439-448. http://dx.doi.org/10.1016/j.jbusvent.2010.01.002

Handoko, H. (2012). Pemodelan Sistem Dinamik Ketercapaian Kontribusi Biodiesel Dalam Bauran Energi Indonesia 2025(Unpublished doctoral dissertation). Institut Pertanian Bogor, Bogor, Indonesia

Hopwood, B., Mellor, M., \& O'Brien, G. (2005). Sustainable development: mapping different approaches. Sustainable development, 13(1), 38-52. $\quad$ Retrieved from http://onlinelibrary. wiley.com/doi/10.1002/sd.244/pdf 
Kumar, S., Shrestha, P., \& Salam, P.A. (2013). A review of biofuel policies in the major biofuel producing countries of ASEAN: Production, targets, policy drivers and impacts. Renewable and Sustainable Energy Reviews,26, 822-836. http://dx.doi.org/10.1016/j.rser.2013.06.007

Mason, C. (2011). Sustaining Competitive Advantage In The Oil Palm Industry: Swot Analysis Of Ioi Corporation. in 2nd International Conference on Business and Economic Research (2nd ICBER 2011) Proceeding. Conference Master Resources.

Mata, T.M., Martins, A.A., Sikdar, S.K., \&Costa, C.A.V. (2011). Sustainability considerations of biodiesel based on supply chain analysis. Clean Technologies and Environmental Policy, 13(5), 655-671. http://dx.doi.org/10.1007/s 10098-010-0346-9

Schmeer, K. (1999). Guidelines for conducting a stakeholder analysis. Bethesda, MD: Partnerships for Health Reform, Abt Associates Inc.

Wirawan, S.S.,\& Tambunan, A.H. (2006). The current status and prospects of biodiesel development in Indonesia: A review. in Third Asia Biomass Workshop.

Yin, R.K. (2013).Case study research: Design and methods. Sage publications Inc, United States of America.

\section{Copyrights}

Copyright for this article is retained by the author(s), with first publication rights granted to the journal.

This is an open-access article distributed under the terms and conditions of the CreativeCommons Attribution license (http://creativecommons.org/licenses/by/4.0/). 